\title{
Yields and its Component Characters in Upland Rice of Manipur
}

\author{
Th. Tilakraj, M. Shyamkesho
}

10.18805/ag.D-5170

\begin{abstract}
Background: Yield is a complex entity. The pre-requisite for achieving high yields in rice depends on identification of superior new genotypes for various traits associated with yield. These characters may help in advancing the yield like the plant height, tillers per plant, length of panicle, grains per panicle, grain weight and their relationship with yield and direct and indirect contribution to grain yield. The present study was conducted to identify the yield and its related characters of all the rice cultivars which are collected from the hill farmers of Manipur.

Methods: Field experiment of 90 local rice cultivars were conducted in the experimental farm of ICAR, Lamphel, Imphal, Manipur. Sample random sampling technique with a sample size of 6 competitive plant were study in the present study. Data of plant height, total tillers per plant, length of panicle, total spikelet's per panicle, grain per panicle, grain weight, grain yield per plant were analysed. Result: The present finding shows that a large number of local cultivars are used by the hill farmers of Manipur without appropriate selection. Some of these cultivars were having those agronomic traits which are considered to be associated with yield characters of rice. If improved high yielding varieties for upland rice cropping is not available to the farmers' they can select to those local cultivars having desirable yield characters.
\end{abstract}

Key words: Cultivars, Panicle, Saved seed, Tiller, Yield indicator

\section{INTRODUCTION}

Rice (Oryza sativa L.) is one of the most important cereal crops. It is source of food to over three and a half billion people and contributes more than $20 \%$ of total dietary calories (Khush, 2013). In India, it covers the largest area under rice about 44.6 million ha of land with a production of about 90.2 million tons (Anonymous, 2009). According to second advance estimates of Government of India, rice production in 2013-14 is likely reaching a record 106.19 million tons (Anonymous, 2014). Upland rice is the staple food of the poorest farmers in Asia and Africa. In the North East India, the major area of upland rice is in the slash and burn system; commonly known as jhum cultivation. In this system, productivity is low and ranges from 0.8-1.2 t/ha (Sarma and Pattanayak 2009).

Manipur, in the North-East region of India, lies between longitude $93.03^{\circ} \mathrm{E}$ to $94.78^{\circ} \mathrm{E}$ and Latitude $23.83^{\circ} \mathrm{N}$ to $25.68^{\circ} \mathrm{N}$ with a total geographical area of $22,327 \mathrm{sq} . \mathrm{km}$. the land may be divided into two districts physiographical division - the hills comprising 90 per cent of the geographical area with five revenue districts viz, Chandel, Churachandpur, Senapati, Tamenglong and Ukhrul and the valley occupying only 10 per cent with four revenue districts. The total acreage under rice crop during 2014-15 crop season is 2,24,380 ha with a total grain production of $3,98,060$ tonnes. Out of the total acreage under rice crop the share of the five hill districts is $8,88,20$ ha with an annual production of $1,40,840$ tonnes. On the other hand, the four valley districts produced $2,57,220$ tonnes from an acreage of $1,35,560$ ha (Table 1 ). Thus, the rice productivity of the hill districts is very low in comparison to valley districts. According to 2001 census, the population of Manipur has been reported as 2.312 million with a total estimated rice requirement of about 485.5 thousand metric
Manipur University, Chachipur-795 003, Imphal, Manipur, India.

Corresponding Author: Th. Tilakraj, Manipur University, Chachipur795 003, Imphal, Manipur, India. Email: tilakigc2016@gmail.com

How to cite this article: Tilakraj, Th. and Shyamkesho, M. (2022). Yields and its Component Characters in Upland Rice of Manipur. Agricultural Science Digest. DOI: 10.18805/ag.D-5170.

Submitted: 18-03-2021 Accepted: 21-12-2021 Online: 18-01-2022

tonnes. Whereas the average production productivity of Manipur per annum is about 477.21 thousand metric tonnes and 2246 kgs. per hectare, respectively, estimating an annual deficit of about 8.289 thousand metric tonnes (Annonymous, 2001). Since, the availability land area for cultivation of rice is limited, we need to increase the production and productivity of rice to meet the deficiency of total rice requirement of the state through intensification of cropping by adopting rice based multiple cropping system, wherever possible, and through increase use of superior genotypes for higher yielding potentiality with appropriate production technology.

Yield is a complex entity. The pre-requisite for achieving high yields in rice depends on identification of superior new genotypes for various traits associated with yield Ramalingam et al., (1993) observed that total filled grains showed both positive genotypic association as well as direct effect on rice yield. Similarly, many workers also attempted to identify the major contributing components of yield in rice like plant height, number of productive tillers, panicle length, number of grains per panicle and test grain weight and their relationship with yield and direct and indirect contribution to grain yield (Mahajan et al.,1981; Ghorai and Pandey, 1982). 
Keeping them in view, the present study was conducted to identify the yield and its related characters of all the rice cultivars which are collected from the farmers of the 5 hill districts of Manipur.

\section{MATERIALS AND METHODS}

Seed samples of rice cultivars were collected from the five hill districts of Manipur during the year 2014-15. Method of seed samples collection as per the suggestion made by Chang et al. (1972) i.e. collection from farmer's home of about $500 \mathrm{~g}$ of seed. The seed samples under the same local name were sorted out for examination.

Field experiments of 90 local rice cultivars were conducted in the Experimental Farm of the ICAR, Lamphal, Imphal (Manipur). The Experimental Farm is located in $24^{\circ}$ $48^{\prime} 35^{\prime \prime}$ latitude and $93^{\circ} 52^{\prime} 75^{\prime \prime}$ longitude with an attitude of $790 \mathrm{~m}$ above MSL. The climate is sub-tropical with a maximum temperature of about $35^{\circ} \mathrm{C}$ during the month of May and June and a minimum of about $0^{\circ} \mathrm{C}$ during December and January. The experimental field has clayey soil and $\mathrm{pH}$ of about 5.5 .

After appropriate preparation of the soil, seeds of the 90 rice cultivars were sown directly separately in separate beds at the seed rate of $80 \mathrm{~kg} / \mathrm{ha}$. Fifty seedling were uprooted after 25 days of sowing and transplanted at a spacing of $20 \mathrm{~cm}$ row to row and $15 \mathrm{~cm}$ plant to plant in the well puddle experimental field with 2 replications. For other management practices, recommended package of practices of growing a good rice crop were followed. However, no fertilizers, no fungicidal or insecticidal spray was used.

Simple random sampling technique with a sample size of 6 competitive plants hill was followed in the present studies. Each plant hill was taken as a sampling unit. The boarder rows were excluded while taking the samples. Data were analysed for the following parameters:

\section{a) Plant height}

Plant height was measured in $\mathrm{cm}$ at maturity by recording the height from the ground level to the tip of the tallest panicle.

\section{b) Total number of tillers per plant}

Total number of tillers was recorded by counting the number of tillers in a random sample size of 6 plants at maximum tillering stage.

\section{c) Length of panicle}

Length of the panicle in $\mathrm{cm}$. was measured as the distance from the neck node to the tip of the panicle.

\section{d) Total spikelet's per panicle}

The total number of spikelets per panicle was recorded by counting the filled and unfilled grains in each panicle.

\section{e) Grain per panicle}

The total number of grains per panicle was recorded by counting the filled grain in each panicles discarding the sterile spikelet's.

\section{f) $\mathbf{1 0 0}$ grain weight}

Weight of 100 filled grains was recorded after harvesting, threshing and winnowing from 6 random plants and expressed the grain yield per plant as their mean.

\section{g) Grain yield per plant}

Grain yield per plant was recorded after harvesting, threshing and winnowing from 6random plants and expressed the grain yield per plant as their mean.

\section{RESULTS AND DISCUSSION}

A large number of local varieties of rice are still widely cultivated by the farmers of five hill districts of Manipur. It shows that the farmers are not well aware of the benefits of modern agricultural practice and of using high yielding varieties. The worth of a cultivar is determined by the worth of its agronomic characters, particularly the grain yield. Grain yield is a product of major components of agronomic characters like plant height, number per panicle and grain weight. Table 1 shows the plant and yield characters, viz., plant height, total tillers per plant, panicle length, spikelet's per plants, grains per panicle, 100 grain weight and grain yield per plant of the rice cultivars grown by framers in the 5 hill districts. Table 2 shows the maximum and minimum ranges of the six yield components.

The plant height as high as $164.28 \mathrm{~cm}$. among the cultivars was recorded from the cultivar Ohuro and 150.40 $\mathrm{cm}$ from Leitan apouba. However, Thoibi $(78.53 \mathrm{~cm})$, Tombung $(79.35 \mathrm{~cm})$ and Nabdumi $(80.73 \mathrm{~cm})$ were the cultivars having the plant height less than $100 \mathrm{~cm}$. Such a great variation in the plant height of local upland rice cultivation would certainly give an opportunity of developing varieties of different plant height for varied ecological conditions of Manipur hills.

Among the rice cultivars of Manipur hills, total number of tillers per plants was highest from the cultivars Noining 10.67 and lowest from the cultivars Chanapati 5.24. As far as spikelet's and grains per panicle were concerned, Sahoksan recorded with the highest number of spikelet's (289.33) and 232.17 grain per panicle. Mankok had the highest panicle length of $35.20 \mathrm{~cm}$ and Kiujimangm had the lowest with $18.48 \mathrm{~cm}$. Also, Mankok had the highest grain weight of $4.02 \mathrm{~g}$ per 100 grains and Phou amuba had the lowest with $1.68 \mathrm{~g}$ per 100 grains. The highest grain yield per plant was recorded from the cultivar Akhanphou (39.55 g).

The highest plant height was found in Ohuru (164.28 $\mathrm{cm}$ ) and its grain yield/plant was $35.44 \mathrm{~g}$., but highest grain yield/plant was found in Akhanphou (39.55 g) and its height was $136.78 \mathrm{~cm}$. Rahimi et al. (2010) reported the presence of the significant negative correlation between plant height and rice grain yield.

However, in the present study panicle length recorded positive effect on grain yield as reported by Toshimenla et al. (2016) followed by grain number as reported by Ghorai and Pandey (1982) and plant height was observed by Mani 
Yields and its Component Characters in Upland Rice of Manipur

Table 1: Yield component of rice cultivars grown by hill farmers of Manipur.

\begin{tabular}{|c|c|c|c|c|c|c|c|}
\hline $\begin{array}{l}\text { Name of } \\
\text { cultivars }\end{array}$ & $\begin{array}{l}\text { Plant height } \\
\quad(\mathrm{cm})\end{array}$ & $\begin{array}{l}\text { Total tillers } \\
\text { per plants }\end{array}$ & $\begin{array}{l}\text { Panicle length } \\
\qquad(\mathrm{cm})\end{array}$ & $\begin{array}{c}\text { Spikelet's per } \\
\text { panicle }\end{array}$ & $\begin{array}{l}\text { Grains per } \\
\text { panicle }\end{array}$ & $\begin{array}{l}\text { Grains yield } \\
\text { per plant }(\mathrm{g})\end{array}$ & $\begin{array}{l}100 \text { Grain } \\
\text { weight }(\mathrm{g})\end{array}$ \\
\hline Ansharang ma & 153.57 & 7.50 & 30.28 & 172.17 & 143.33 & 33.36 & 3.45 \\
\hline Akhanphou & 136.38 & 10.17 & 24.32 & 163.17 & 141.50 & 39.55 & 3.21 \\
\hline Akia & 102.42 & 8.67 & 20.08 & 129.67 & 93.67 & 23.39 & 2.45 \\
\hline Bilkuangbuh & 133.67 & 6.83 & 24.38 & 106.83 & 82.17 & 20.54 & 2.93 \\
\hline Bounga & 125.60 & 7.67 & 20.10 & 169.83 & 113.33 & 22.56 & 2.73 \\
\hline Bungpat & 95.28 & 5.50 & 25.70 & 283.67 & 197.33 & 27.42 & 2.1 \\
\hline Buhman & 130.47 & 5.67 & 23.45 & 135.00 & 113.33 & 25.85 & 3.05 \\
\hline Burma phou & 132.87 & 7.83 & 29.23 & 246.17 & 180.50 & 28.63 & 2.84 \\
\hline Chahao & 134.45 & 6.50 & 24.57 & 175.00 & 123.33 & 23.60 & 3.14 \\
\hline Champi & 134.20 & 6.50 & 25.55 & 185.33 & 170.50 & 29.30 & 2.94 \\
\hline Champra & 133.60 & 7.17 & 21.60 & 138.17 & 120.00 & 30.44 & 3.29 \\
\hline Chanapati & 112.63 & 5.24 & 25.18 & 153.33 & 120.67 & 18.49 & 2.47 \\
\hline Chandrakriti & 124.58 & 7.83 & 22.42 & 186.17 & 153.83 & 30.11 & 3.12 \\
\hline Chandrashaker & 89.50 & 5.67 & 21.57 & 139.33 & 115.00 & 29.23 & 3.63 \\
\hline Changat & 132.47 & 6.83 & 25.18 & 249.00 & 198.33 & 31.17 & 2.43 \\
\hline Changlei & 110.82 & 8.33 & 25.48 & 172.17 & 147.50 & 30.30 & 2.56 \\
\hline Changman & 143.15 & 5.67 & 32.37 & 195.17 & 155.50 & 28.10 & 2.91 \\
\hline Chapheng & 122.58 & 5.50 & 23.53 & 165.67 & 110.33 & 16.55 & 1.99 \\
\hline Chinaphou & 125.32 & 5.67 & 23.25 & 138.50 & 98.33 & 19.72 & 2.51 \\
\hline Chingphou & 114.38 & 5.50 & 25.60 & 123.67 & 84.33 & 23.40 & 2.73 \\
\hline Chyampokpi & 84.17 & 6.83 & 21.60 & 115.17 & 51.17 & 13.85 & 3.2 \\
\hline Gulbuh & 144.62 & 6.50 & 26.42 & 164.17 & 119.50 & 20.52 & 2.32 \\
\hline Huikap & 90.65 & 7.50 & 23.47 & 110.33 & 83.33 & 23.56 & 2.97 \\
\hline R.I & 80.68 & 6.50 & 22.63 & 127.33 & 95.67 & 22.24 & 2.24 \\
\hline Istoma & 129.52 & 7.33 & 25.35 & 169.50 & 146.17 & 27.90 & 3.01 \\
\hline Kahaola & 137.68 & 7.33 & 23.60 & 150.00 & 125.33 & 26.68 & 3.02 \\
\hline Kakcheng & 138.55 & 7.67 & 24.70 & 172.50 & 114.67 & 19.50 & 2.47 \\
\hline Kaphuza & 138.40 & 8.50 & 29.13 & 178.17 & 140.50 & 28.32 & 2.31 \\
\hline Karlong & 112.30 & 5.33 & 23.78 & 106.50 & 84.17 & 15.46 & 3.08 \\
\hline K.D. & 82.43 & 7.50 & 22.58 & 180.33 & 150.83 & 38.43 & 2.84 \\
\hline Khonghing & 140.22 & 7.33 & 24.58 & 195.17 & 142.17 & 18.18 & 2.75 \\
\hline Kiophou & 103.65 & 8.00 & 22.05 & 113.17 & 85.83 & 23.21 & 2.51 \\
\hline kiujimang & 128.48 & 6.17 & 18.47 & 124.67 & 97.67 & 23.29 & 2.02 \\
\hline Kumbi phou & 123.12 & 7.67 & 21.50 & 163.33 & 113.83 & 27.37 & 2.47 \\
\hline Lainingphou & 98.52 & 10.03 & 24.55 & 125.00 & 98.67 & 26.48 & 2.96 \\
\hline Lamyang & 125.37 & 6.50 & 30.13 & 136.17 & 98.50 & 28.82 & 2.86 \\
\hline Langmei & 135.08 & 6.83 & 27.60 & 130.67 & 115.33 & 27.41 & 3.01 \\
\hline Langphou & 127.60 & 7.33 & 23.48 & 194.17 & 172.50 & 32.82 & 2.79 \\
\hline Leitan & 148.65 & 6.83 & 26.20 & 233.00 & 187.67 & 33.77 & 3.3 \\
\hline Leitan apouba & 150.40 & 6.50 & 24.37 & 193.50 & 126.50 & 30.47 & 3.12 \\
\hline Lubanglong & 83.73 & 5.50 & 22.30 & 182.17 & 115.67 & 25.35 & 3.2 \\
\hline Miri & 89.77 & 5.67 & 19.75 & 102.67 & 50.33 & 15.35 & 2.58 \\
\hline Milong Tei & 99.48 & 7.33 & 21.35 & 120.50 & 92.50 & 13.76 & 2.94 \\
\hline Majinlipui & 103.48 & 5.50 & 19.45 & 119.33 & 85.17 & 18.57 & 3.19 \\
\hline Mama ma & 125.15 & 8.83 & 26.13 & 132.83 & 84.17 & 23.24 & 2.69 \\
\hline Maneyo & 133.32 & 6.67 & 22.42 & 126.33 & 103.33 & 27.61 & 2.69 \\
\hline Mankok & 145.33 & 7.50 & 35.20 & 212.33 & 172.83 & 38.89 & 4.02 \\
\hline Maorola & 131.60 & 7.83 & 19.48 & 92.50 & 87.00 & 15.32 & 2.47 \\
\hline Marongza & 129.37 & 6.50 & 24.80 & 146.33 & 112.67 & 18.30 & 2.39 \\
\hline
\end{tabular}

Table 1: Continue..... 
Yields and its Component Characters in Upland Rice of Manipur

Table 1: Continue....

\begin{tabular}{|c|c|c|c|c|c|c|c|}
\hline Matei mata & 130.27 & 5.50 & 21.60 & 139.33 & 103.17 & 25.49 & 3.43 \\
\hline Maziiro & 124.28 & $6 . .50$ & 26.67 & 153.17 & 129.17 & 27.03 & 2.15 \\
\hline Mikroro & 122.10 & 8.67 & 23.45 & 155.50 & 125.50 & 32.77 & 3.28 \\
\hline Mohor & 104.55 & 5.67 & 23.08 & 183.83 & 170.33 & 24.17 & 2.38 \\
\hline Mojha & 132.77 & 7.50 & 20.13 & 129.50 & 104.33 & 20.37 & 2.35 \\
\hline Moirangphou & 127.83 & 9.33 & 23.45 & 140.33 & 120.17 & 32.70 & 3.03 \\
\hline Moirangphou amubi & 132.35 & 7.33 & 21.67 & 132.67 & 107.50 & 25.46 & 2.8 \\
\hline Moirangphou chingi & 88.80 & 6.33 & 27.10 & 218.17 & 192.17 & 29.94 & 2.17 \\
\hline Moirangphoukhongnamb & i 86.40 & 5.50 & 24.52 & 152.17 & 123.50 & 22.78 & 3.05 \\
\hline Nabdumei & 80.73 & 5.50 & 23.45 & 168.33 & 115.17 & 18.48 & 2.96 \\
\hline Nagahongma & 122.20 & 6.83 & 26.28 & 149.33 & 103.00 & 19.92 & 2.47 \\
\hline Nagaphou & 75.60 & 7.83 & 21.33 & 143.33 & 98.67 & 18.49 & 2.52 \\
\hline Naga special & 136.32 & 6.67 & 23.28 & 152.83 & 120.67 & 20.46 & 2.46 \\
\hline Napadai & 115.42 & 5.83 & 27.25 & 194.50 & 177.50 & 28.77 & 2.84 \\
\hline Noining & 137.37 & 10.67 & 14.48 & 247.33 & 103.33 & 38.83 & 3.32 \\
\hline Nungsii & 116.45 & 6.67 & 25.42 & 149.67 & 103.50 & 24.63 & 2.34 \\
\hline Ohuro & 164.28 & 6.33 & 27.25 & 253.17 & 220.50 & 35.44 & 2.89 \\
\hline Oriyo & 124.45 & 6.50 & 19.55 & 103.50 & 90.17 & 20.47 & 3.45 \\
\hline Palbem & 110.90 & 5.83 & 25.45 & 119.83 & 80.50 & 19.06 & 3.02 \\
\hline Milong Tei & 81.57 & 5.50 & 21.47 & 108.33 & 49.33 & 15.47 & 2.8 \\
\hline Phaichang & 93.53 & 5.50 & 22.82 & 129.50 & 93.50 & 17.30 & 2.43 \\
\hline Phe charang & 125.47 & 6.17 & 24.42 & 158.00 & 124.67 & 23.49 & 2.92 \\
\hline Phe charo & 138.62 & 6.83 & 27.57 & 143.17 & 120.17 & 28.07 & 3.02 \\
\hline Phou amuba & 134.36 & 5.67 & 24.68 & 163.33 & 74.83 & 14.44 & 1.68 \\
\hline Phourem & 137.37 & 7.67 & 23.07 & 192.17 & 127.17 & 39.09 & 3.35 \\
\hline Phoudum & 110.40 & 6.83 & 20.13 & 127.33 & 80.17 & 19.41 & 2.67 \\
\hline Phuring & 138.43 & 9.00 & 24.62 & 166.50 & 146.33 & 29.33 & 2.56 \\
\hline Pumba phou & 113.48 & 6.67 & 22.42 & 132.50 & 95.67 & 21.41 & 2.63 \\
\hline Ramchang ma & 147.84 & 8.67 & 29.67 & 205.50 & 188.50 & 32.45 & 3.03 \\
\hline R.C.M. & 93.63 & 7.67 & 23.25 & 125.50 & 85.33 & 29.27 & 2.8 \\
\hline Sahoksan & 143.28 & 7.50 & 27.30 & 289.33 & 232.17 & 36.46 & 2.47 \\
\hline Siroima & 88.40 & 5.50 & 27.57 & 207.33 & 150.17 & 26.45 & 2.73 \\
\hline Sulam phou & 140.33 & 5.50 & 27.57 & 207.33 & 150.17 & 26.45 & 2.73 \\
\hline Thaisen & 90.47 & 6.67 & 21.53 & 105.00 & 89.50 & 23.46 & 2.86 \\
\hline Thoibi & 78.54 & 7.67 & 23.55 & 104.33 & 80.17 & 25.19 & 2.82 \\
\hline Thinjachang & 141.60 & 8.33 & 22.92 & 246.33 & 213.33 & 30.06 & 3.11 \\
\hline Tolen phou & 128.27 & 5.67 & 22.65 & 132.33 & 117.67 & 25.63 & 2.77 \\
\hline Tombung & 79.35 & 7.83 & 28.50 & 98.33 & 85.50 & 18.61 & 2.98 \\
\hline Torangza & 123.52 & 8.50 & 21.30 & 153.50 & 122.50 & 24.30 & 2.55 \\
\hline Unidentified & 136.55 & 7.67 & 22.67 & 116.33 & 96.17 & 21.42 & 2.82 \\
\hline Yaphurma & 139.22 & 5.67 & 22.68 & 172.50 & 127.50 & 20.45 & 3.38 \\
\hline Mean & 119.850 & 6.983 & 24.1555 & 158.343 & 121.323 & 25.973 & 2.799 \\
\hline CV & 17.911 & 20.998 & 14.208 & 26.998 & 31.380 & 61.9444 & 14.182 \\
\hline CD 5\% & 3.195 & 1.037 & 2.182 & 7.694 & 5.790 & 16.264 & 1.100 \\
\hline
\end{tabular}

(1981). Similarly, Mankok has the highest panicle length $(35.20 \mathrm{~cm})$ and its yield/plant was $38.42 \mathrm{~g}$ which was the third highest yield/plant but for Akhanphou panicle was 24.32 $\mathrm{cm}$. This was slightly contrast with the observation of Paramasivan and Sree Rangasamy (1988) where plant height and panicle length also had strong positive association with grain yield as well as productive tillers/plant. International Rice Research Institute (IRRI) (1997) stated that traits contributing to yield potential in rice include tillering ability, leaf length, leaf width, number of leaf, number of panicle length of grain and amount of grains on the panicle.

The highest productive tillers/plants were found in Noining (10.67) and which was second highest grain yield/ plant $(38.83 \mathrm{~g})$ whereas the highest grain yield/plant was Akhanphou $(39.55 \mathrm{~g})$ but which produced second highest productive tiller/plant (10.17). Grain weight and tiller number 
Table 2: Diversity of Agronomic character of 90 local cultivars of Manipur hill.

\begin{tabular}{lcc}
\hline Character & Minimum & Maximum \\
\hline Plant height & 164.28 & 78.54 \\
Total no. tillers per plants & 10.67 & 5.24 \\
Panicle length (cm) & 35.20 & 18.47 \\
Spikelet's per panicles & 289.33 & 92.47 \\
Grains per panicle & 232.17 & 49.35 \\
100 grain weight $(\mathrm{g})$ & 4.02 & 1.68 \\
Grain yield per plant $(\mathrm{g})$ & 39.55 & 13.82 \\
\hline
\end{tabular}

exhibited positive direct effect on yield as observed by Mani (1981). Sundaram et al. (1988), Paramisavan and Sree Rangasamy (1988) and Mahajan (1993) also reported that the highest degree of association between the productive tillers/plant and grain yield indicated that number of productive tiller/plant is highly reliable component of yield and can very well be utilized as an yield indicator in yield trials. Gravois and Helms (1992) showed that at different seeding rates, the direct effects of filled grain panicle-1 on rice yield were moderate and positive. Ramalingam et al., (1993) observed that total filled grains showed both positive genotypic association as well as direct effect on rice yield.

Gopinath et al. (1984) also considered productive tiller/ plant and filled grains/panicle important yield component of rice. The 100 grain weight had high + ve contribution towards yield, but indirect contribution of it via tillers/plant and filled grain/panicle. The present findings were in accordance with the findings by Mahalingam et al., (2012).

\section{CONCLUSION}

The present finding shows that a large number of local rice cultivars are used by the hill farmers without appropriate selection. Some of these cultivars were having those agronomic traits which are considered to be associated with yield characters of rice. If improved high yielding varieties for upland rice cropping is not available to the farmers they can select those local cultivars having desirable yield characters. A more intensive study in this area for selection of those rice cultivars with high yielding traits will be fruitful.

\section{REFERENCES}

Anonymous. (2001). Annual plan 2001-02. Depatment of Agriculture, Government of Manipur. p 6.

Anonymous (2009). Agricultural Statistics at a Glance. Directorate of Economics and Statistics.
Department of Agriculture and Cooperation, Ministry of Agriculture, Government of India. Pp 359.

Anonymous (2014). http://www. Oryza.Com.

Chang, T.T., Sharma, S.D., Adair, C.R. and Perez, A.T. (1972). Manual for Field Collectiors of rice. IRRI, los Banos, Phillippines. p. 32.

Ghorai, D.P. and Pandey, K. (1982). Inheritance of yield and yield components and their association in a rice cross AC1063 x AC 27. Oryza. 19: 185-187.

Gopinath, M., Rama Reddy, N. and Subramanyan, D. (1984). Studies on character association of rice. Andra Agricultural Journal. 1: $102-5$

Gravois, K.A. and Helms, R.S. (1992). Path analysis of rice yield and yield components as affected by seeding rate. Agron J. 84: 1-4.

Khush, G.S. (2013). Strategies for increasing the yield potential of cereals: Case of rice as an example. Plant Breeding. 132: 433-436.

IRRI (International Rice Research Institute), (1997). Evaluating local germplasm for the upland rice ecosystem in Western Nepal. Inter Rice Res. Notes. 22(1): 31-32.

Mahajan, R.K., Rao, A.V. and Agrawal, D.K. (1981). Principal component analysis in some late maturing rice varieties, Indian $\mathrm{J}$. Agric. Sci. 51: 9-12.

Mahajan, C.R. (1993). Correlation studies in F4 progenies of upland rice. Annals of Agricultural Research. 14(2): 215-217.

Mani,M. (1981). Genetic potentialities of contrasting plant types in $\mathrm{F}_{2}$ of three rice (Oryza sativa L.) cross. M.Sc.(Ag.) Thesis. Tamil Nadu Agil. Univ., Coimbatore.

Mahalingam, A., Saraswathi, R., Ramalingam, J. and Jayaraj, T. (2012). Genetic studies on divergence and phenotypic characterization of indigenous and exotic indica germplasm lines in rice (Oryza sativa L.). African Journal of Agricultural Research. 7: 3120-3128.

Paramasivan, R.S. and Shee Rangasamy, S.R. (1988). Genetics analysis of yield and its components in rice. Oryza. 25(2): 11-19.

Rahimi, M., Rabiei, B., Samizadeh, H. and Ghasemi, A.K. (2010). Combining ability and heterosis in rice (Oryza sativa L.) cultivars. J. Agr. Sci. Tech. 12: 223-231.

Ramalingam, J., Ndarajan, N., Vanniarajan, C. and Rangasamy, P. (1993). A path coefficient analysis of panicle traits. Int. Rice Res. Notes. 18(1): 20-21.

Sarma, B.K., Pattanayak, A. (2009). Rice Diversity of North East India. Millenium Publisher, Guwahati, India.

Sundaram, T., Wilfred Manuel, W. and Palanisamy, S. (1988). Genetic variability and correlation in early rice (Oryza sativa). Indian Journal of Agricultural Science. 58(8): 529-30.

Toshimenla, Singh, J. and Changkija, S. (2016). Genetic divergence studies on upland rice grown in Nagaland, India. Indian J. Agri. Res. 50(6): 555-560. 